\title{
THE PRACTICE OF USING THE GOLDEN SECTION IN ARCHITECTURE IN THE CITY OF RYAZAN
}

\author{
Svetlana Pravdolyubova ${ }^{1}$, Mikhail Vekilyan ${ }^{1}$, Gennadiy Nechiporuk ${ }^{1}$, Anna Kozhnova ${ }^{1}$, Svetlana Guseva ${ }^{2}$ \\ ${ }^{1}$ Ryazan Institute (branch) of Moscow Polytechnic University \\ Pravo-Lybedskaya st., 26/53, Ryazan, Russia \\ ${ }^{2}$ Maranda Ltd. \\ Poletaeva st., 24, Ryazan, Russia
}

*Corresponding author: pravda_63@mail.ru

\begin{abstract}
Introduction: At present, the preservation of unique architectural ensembles is one of the most urgent problems of sustainable development in historical settlements. In the context of transforming the settlement's environment while minimizing the discordant impact of new construction, it is important to study the development sites that will be used as the basis for modern planning. Method: The article applies the method of geometric analysis to the historical buildings of the city of Ryazan, which exhibit classical architecture traits and were designed by the $19^{\text {th }}$ - and $20^{\text {th }}$-century architects, in order to assess their compliance with the rules of classical composition, specifically the use of golden section proportions. We also talk about the golden section in general, reviewing its history and the rules of its application in architecture. Results: We emphasize the inseparable link between architecture and geometry. Our study proves that the golden section principles were used by architects during different historical periods. In the context of the invariably high interest towards the creative heritage of architects from the $19^{\text {th }}$ and $20^{\text {th }}$ centuries and the need to build upon their historical experience, it is highly relevant to approach the modern architectural practice from the standpoint of using the canon of Neoclassical architecture.
\end{abstract}

\section{Keywords}

Golden section, golden ratio, cultural heritage sites, architecture, geometric analysis, buildings, structures, Neoclassical period, proportionality, design technique, geometric progression, facade, column, stylobate, entablature, capital, form-making.

\section{Introduction}

The beginning of the reform that divided Russia into governorates, as well as the deployment of new principles of regular structural development, saw the creation (as per the general plan issued by Catherine the Great) of a new square, buildings, and street layouts that have survived to this day. The designs of these sites belong to the Neoclassical style; some examples include: the building of the men's gymnasium, the drama theater in the Sobornaya Square, and the indoor market in the Bazarnaya Square. Some of Ryazan's buildings and structures make up the historical development stock, serving as the background for the emerging Soviet architecture, which, in turn, was the link between the architecture of the past and modern architecture (Guseva and Pravdolyubova, 2017a).

We have made an attempt at studying various cultural heritage sites and at understanding their true features, as well as the cause-and-effect relationship between expressive architectural details and building elements from different periods. To achieve this goal, we have made a selection of historical buildings, dating from the second half of the $18^{\text {th }}$ century to the $1960 \mathrm{~s}$. As a result, we have examined over a dozen architectural and cultural heritage sites in Ryazan and the Ryazan Region.

This particular paper focuses on two of these buildings, functionally diverse and still in use for their intended purpose:

- the men's gymnasium, built in the $19^{\text {th }}$ century by architect M. F. Kazakov and currently housing the polytechnic university;

- the drama theater building, which is the main image-shaping landmark of the Teatralnaya Square.

The concept of the golden section, elevated to the rank of the main aesthetic principle, was described by Leonardo da Vinci as the "Golden Number» (Kvashina and Gorovenko, 2017). His teachings faded into oblivion for almost two hundred years; it was not until the middle of the $19^{\text {th }}$ century that another attempt was made to formulate the general principles of proportionality and the golden («divine») ratio (Piljasov, 2012).

There are infinite irrational numbers; however, a select few of them hold a special place in the history of spiritual and material culture, architecture, and mathematics. One of such numbers is the Phidias number (phi), which equals $1.618 \ldots$ and is the result of solving a geometrical problem: dividing a line segment into two unequal parts in such a way that the ratio of its larger part to the smaller part is the 
same as the ratio of the entire segment to the larger part (Suprun et al., 2019).

This mathematical proportion was used for formmaking in the art of architecture. Its purpose was to facilitate a harmonized, holistic perception of the man-made urban environment. Architecture, which intersects with geometry in many ways by its sheer nature, has a long history of using measurements and observing proportions (Kalashnikova and Gorovenko, 2016). The golden section principle also lies at the foundation of construction metrology. The ratio of the general structure to the specific details in different structures' proportions presents sufficient material for studying the development of the golden section canon, as represented by harmonizing the appearance of urban buildings (Gamm and Gorovenko, 2016). The emergence of a new world view and new methodologies in the design of buildings and structures, as well as the advent of new construction techniques and modern materials, creates a new attitude to form, proportions, and aesthetic (Guseva and Pravdolyubova, 2017b). The quintessential goal of this study is an attempt to trace the application of this methodology to designing Neoclassical buildings and structures, as well as its interpretation in Ryazan's architecture in the 1930s and 1950s.

We limited our efforts to demonstrating the results of analyzing the geometry of a limited number of public buildings, which represent the Neoclassical school of architecture, with a particularly in-depth look at the geometric proportions of individual elements and fragments. "The composition of churches is perfectly measured, and the architects must follow these measurements with utmost diligence. They arise from proportion.

And proportion is the balance between the parts of any work of architecture separately and as a whole, in relation to a single part, which any harmonious measurement is founded on. For the fact of the matter is that no church shall have proper composition without harmony and proportion, and without being divided into parts the same way as a well-built human body. After all, nature did create the human body in a very particular way, so that the face, from the chin to the hairline, equals one tenth of the body's length... the head and the neck, from the upper chest to the hairline, equals one sixth... the foot equals one sixth" (Shevelyov, 1995).

Only when we do understand the role of proportionate division into parts and the ratio of the parts to the whole, only then shall we understand the measurement canon that the architects of the past had mastered (Shevelyov, 1995). The goal of architectural measurement is to bind all elements of the building together with a proportional relationship so that everything would be unified and all the individual elements would be subordinated to the core (Radzyukevich, 2014).

«Each work of art, just like any living being, has its own proportions, its own sequence of rhythmically measured flows, dictated by the form. This makes our goal quite clear: use the living, everlasting examples from the architecture of the past to demonstrate how the compositional structure, association imagery, and proportion measurements are all tied together, thus making it possible to experience the profound meaning of true professional mastery» (Shevelyov, 1995).

It has been common practice in mathematics, since the Renaissance at the latest, to single out a specific method of dividing an entity into two unequal segments; this method is based on two different types of relationship between the parts and the whole: additive and multiplicative. This was how the proportions of the golden section, known back in ancient times, were described during that period (Gorovenko and Gorovenko, 2017; Grinchenko and Shchapova, 2018). The unity of the additive and multiplicative relationship is where the deep meaning of the golden section lies; this unity is the key to the phenomenon of form-making, which can be clearly seen on the surface of mathematical knowledge. The notion of the additive relationship shows that the whole has a structure. The simplest, most elementary whole entity is made out of two parts. In mathematics, the abstract representation of this structure is the operation of addition: part a plus part $b$ equals the whole, $c$. In geometry, this can be illustrated by a line segment divided in two. If these two parts of the segment are unequal, and the ratio of the smaller part to the larger part is the same as the ratio of the larger part to the whole, this means that the additive relationship and the multiplicative relationship overlap, and the line segment is divided according to the golden section principle. The multiplicative relationship means that all parts of a structurally organized whole are subject to the same growth principles (Bondarenko, 2019; Stakhov, 1984, 2012). Mathematical tools show that both the parts of the whole and the whole itself have the same capacity for changing their parameters: within a single living body, all parts grow according to one law: the law of geometric progression. The more one part grows, the larger (by the same multiplier) the other part becomes, and the whole with it (a:b $=b: c$ ). Consequently, the whole (c), if examined independently from the surrounding context, always remains identical to itself at any point throughout its existence.

Numerically, the golden section can be described as follows: $\Phi^{-1}=0.618$ and $\Phi^{-2}=0.382$.

Analyzing the Building of the Ryazan Regional Drama Theater

As the first item for examination, we propose the building of the Ryazan Regional Drama Theater, awarded with the State Badge of Honor. The theater 
was founded in 1787. It has undergone a number of reconstructions since then. The building we see today dates back to 1961 .

We based our analysis on the building's dimensions, as follows:

$$
\begin{aligned}
& \text { width }-34.5 \mathrm{~m} \text {; } \\
& \text { depth }-62 \mathrm{~m} \text {; } \\
& \text { height }-28 \mathrm{~m} \text {. }
\end{aligned}
$$

Let us now compare the ratio of the building's overall dimensions and the golden section canon, i.e. ratio of the smaller part to the larger part and the larger part to the whole:

$$
\begin{gathered}
\text { height }+ \text { width }=\text { depth, } \\
28+34=62 .
\end{gathered}
$$

In this case, at the initial calculation stage, the golden section formula is fully justified, as that the sum of the smaller and larger parts is equal to the whole.

$$
\begin{aligned}
& \frac{\text { height }}{\text { width }}=\frac{28}{34.5}=0.81 . \\
& \frac{\text { width }}{\text { depth }}=\frac{34,5}{62}=0.58(0.6) . \\
& \frac{\text { height }}{\text { depth }}=\frac{28}{62}=0.45(0.5) .
\end{aligned}
$$

Further calculations show that the width/depth and height/depth ratios approach the Phidias number, 0.618 .

Let us make a proportion:

assuming that $\mathrm{x}$ is the height of the roof (architrave + frieze + cornice + pediment);

and $28-x$ is the height of the building (columns + capital).

Then

$$
\frac{x}{28-x}=\frac{28-x}{28} .
$$

After solving for $\mathrm{x}$, we find that: $\mathrm{x}=10.7 \mathrm{~m}(\approx 11 \mathrm{~m})$; $28-10.7=17.3 \mathrm{~m}$ (roof height).

These calculations give us the following: the canonical ratio of the smaller part to the larger part is identically equal to the ratio of the larger part to the whole, which confirms that the building is structured according to the golden section principle.

The drama theater's linear dimensions:

- width $-34.5 \mathrm{~m}$;

- depth $-62 \mathrm{~m}$;

- height $-28 \mathrm{~m}$;

- column circumference - $\mathbf{5 . 2} \mathrm{m}$. The circumference formula $C=\pi d$ helps us find the diameter 5.2:3.14 $\approx 1.65 \mathrm{~m}$;

- column spacing - $2.33 \mathrm{~m}$;

- the distance between the two outer columns on either end $\mathbf{- 0 . 6} \mathrm{m}$;

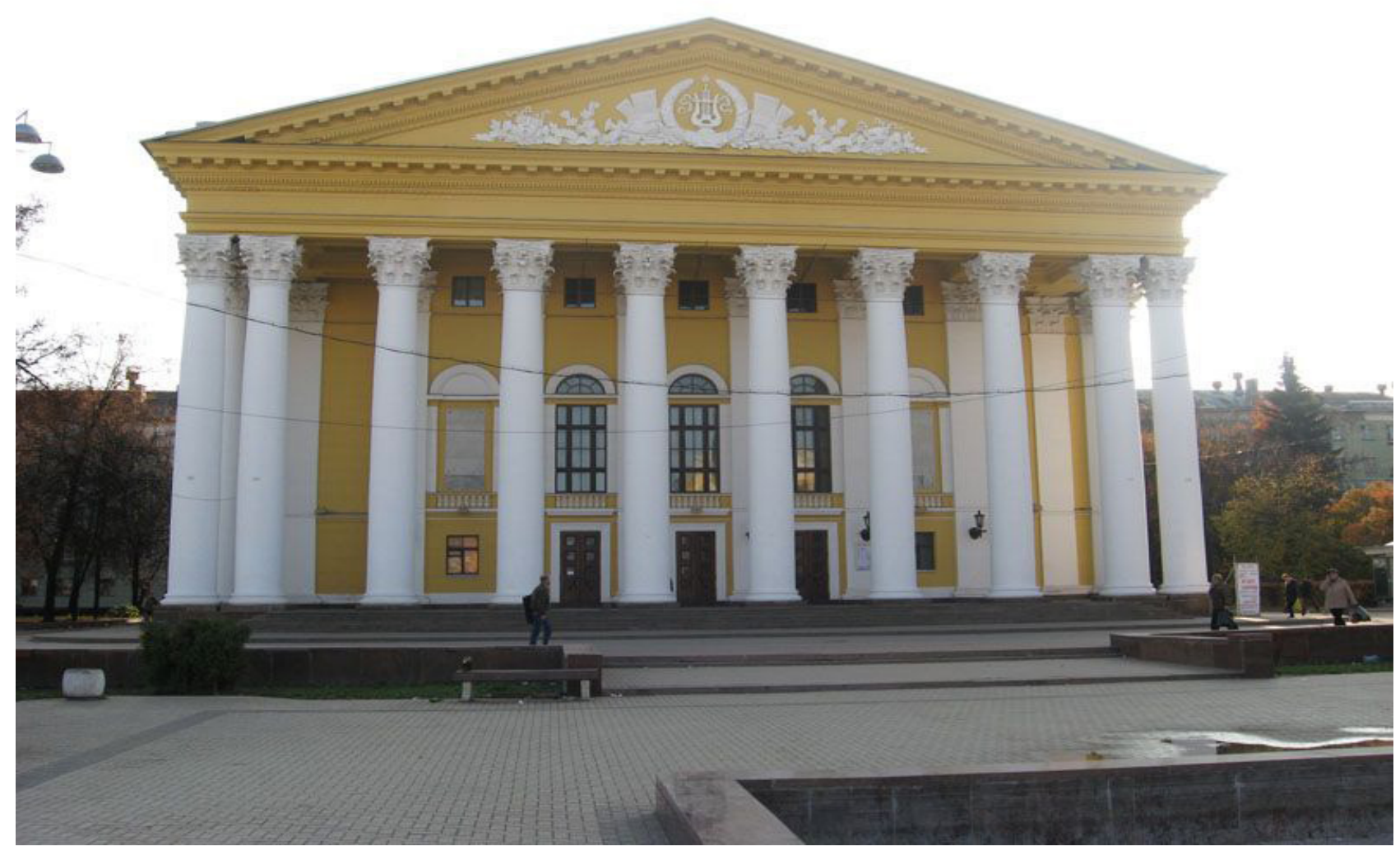

Figure 1. The building of the Ryazan Regional Drama Theater, awarded with the State Badge of Honor 
- roof height (architrave + frieze + cornice + pediment) $-10.7 \mathrm{~m}$;

- entablature width $\approx 4 \mathrm{~m}$;

- stylobate length $-34.5 \mathrm{~m}$.

- pediment height $-6.7 \mathrm{~m}$ : column height + capital $-17.3 \mathrm{~m}$

- the capital height equals:

$$
\frac{17.3}{8}=2.1625 \mathrm{~m} \text {. }
$$

The column shaft height equals: $17.3-2.16=15.4 \mathrm{~m}$.

Let us now measure the colonnade against the theater's rectangular facade. The canon golden section theory is based on the assumption that the column symbolizes the human body (Pankratova, 2018; Stakhov, 2004). This leads to the 1:5 proportion requirement (equal to the ratio of the foot to the overall human height). This proportion requirement applies to a single column (including the capital) and the entire colonnade (Litvinenko and, Luchkova, 2015; Shevelyov et al. 1990).

According to Plato, the mean average is the average derived from two extreme values.

If the task is to make a ratio between the numbers 1 and 5 , the best ratio will be $\sqrt{5}$, since $1: \sqrt{5}=\sqrt{5}: 5$.

The Parthenon ratio is $1: 5$, which directly points to the proportions of the Parthenon as a mean average of 1 and 5, i.e. $1: \sqrt{5}=0.447$. After all, if the column shaft has 1:5 proportions, then the links between the columns in the colonnade (the column spacing) should be the average of the two extreme values, namely the diameter and height of the column shaft; whereas the stylobate width should be the average of the order height and the stylobate length.

The measurements show that:

$\frac{\text { Lower diameter of the corner column }}{\text { Shaft height of the corner column }}=$ $\frac{1.65+1.65 m}{15.14 m}=0,2179 ; 1: 5(+0.0179)$.

Lower diameter of the corner column $=$ Shaft height of the corner column

$$
1,65+\frac{1,65}{15,14}=0,2179 ; 1: 5(+0.0179) \text {. }
$$

Lower diameter of the middle column $=$ Shaft height of the middle column

$$
\begin{aligned}
& \frac{1.65}{15.14}=0.1089 ; 1: 5(-0.0179) . \\
& \frac{\text { Cappital abacus width }}{\text { Column height with capital }} \\
& \frac{2,16}{17,3}=0.1248 ; 1: 5(-0.0752) .
\end{aligned}
$$

$\frac{\text { Column spacing }}{\text { Column shaft height }}=\frac{2,33}{15,14}=0.1538$;

$$
1: 5(-0.0462) \text {. }
$$

$$
\begin{aligned}
& \frac{\text { Pediment height }}{\text { Column shaft height }}=\frac{6.7}{15.14}=0.4425: \sqrt{5}= \\
& \quad=0.447 ;(-0.0045) . \\
& \begin{aligned}
\frac{\text { Column height }+ \text { capital }}{\text { Stylobate length }}=\frac{17.3}{34.5}=0.4942: \sqrt{5}= \\
=0.447 ;(+0.0472) .
\end{aligned}
\end{aligned}
$$

These measurements show that the rectangle of the theater's main facade reinforces the association: the human body is likened to the body of a column and the body of the entire building (colonnade). This reaffirms that the building's metric features of the Regional Drama Theater fit the golden section canon completely.

Analyzing the Building of the Polytechnic Institute

The polytechnic institute is located in a heritage building that dates back to the $19^{\text {th }}$ century (designed by M. F. Kazakov). It is a striking example of Russian Neoclassical architecture and an integral part of the surrounding ensemble in Lenina (formerly Astrakhanskaya) Street.

Plan view of the building's dimensions:

$$
\frac{\text { width }}{\text { depth }}=\frac{54}{90}=0.6 \text {. }
$$

The measurement proportions of the central facade:

$$
\begin{aligned}
& \frac{\text { height of the central facade }}{\text { height of the side wings }}=\frac{25,20}{20,4}=1,23 . \\
& \text { height of the pediment }+ \\
& \begin{array}{c}
\text { height of the first floor with the basement }= \\
=\text { height of the central facade } \\
\\
\quad 3.8+7.75=11.55 \\
\frac{\text { width }}{\text { height }}=\frac{24.0}{21.4}=1.12 .
\end{array}
\end{aligned}
$$

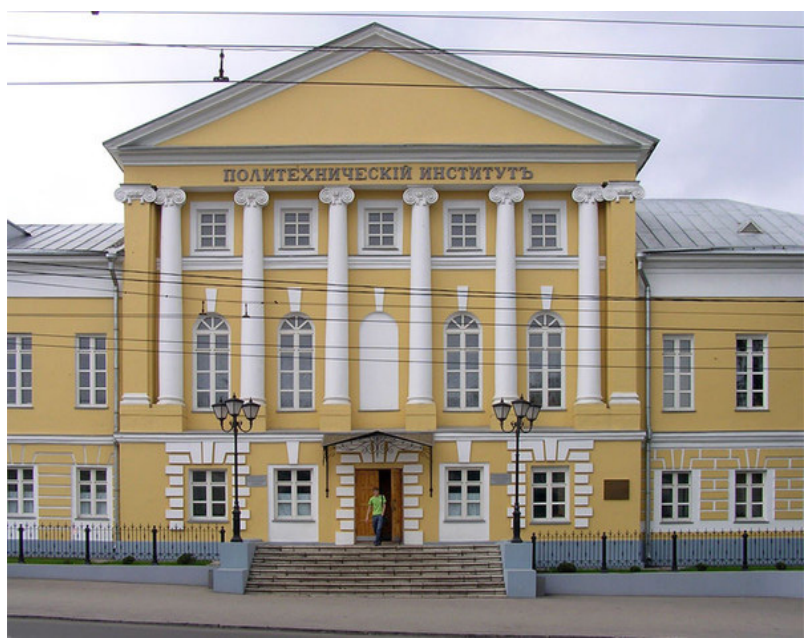

Figure 2. The building of the polytechnic institute 
Vertical articulation ratio

$$
\frac{\text { height of the second }- \text { floor window }}{\text { height of the column shaft }}=\frac{4.5}{7.0}=0.64 \text {. }
$$

Our calculations allow us to assert that the building's overall dimensions match the golden section principle.

Let us now check the main facade's rectangle for compliance with the Parthenon ratio.

$$
\begin{aligned}
& \frac{\text { Lower diameter of the corner column }}{\text { Shaft height of the corner column }}= \\
& \frac{2}{7}=0.2857 ; 1: 5(+0.0857) .
\end{aligned}
$$

Lower diameter of the middle column $=$ Shaft height of the middle column

$\frac{1}{7}=0.1428 ; 1: 5(-0.0572)$.

$$
\begin{aligned}
& \frac{\text { Capital width }}{\text { Column height with capital }}= \\
& \frac{0.7}{7.7}=0.09 ; 1: 5(-0.1100) \text {. } \\
& \frac{\text { Column spacing }}{\text { Shaft height }}= \\
& \frac{1.5}{7}=0.2142 ; 1: 5(=0.0142) \text {. }
\end{aligned}
$$

$\underline{\text { Order height (column + entablature) }}=$ Stylobate length

$$
\frac{9.3}{16}=0.5812 ; 1: \sqrt{5}(-0.1342) \text {. }
$$

$$
\begin{gathered}
\frac{\text { Estimated average column diameter }}{\text { Column spacing }}= \\
\frac{1}{1}=0.6667 ; 1: \sqrt{5}(-02197) . \\
\frac{\text { Pediment height }}{\text { Column shaft height }}=
\end{gathered}
$$

$$
\begin{gathered}
\frac{3,8}{7}=0.5428 ; 1: \sqrt{5}(+0.0958) . \\
\frac{\text { Column height }+ \text { capital }}{\text { Stylobate length }}= \\
\frac{7,7}{16}=0.4812 ; 1: \sqrt{5}(+0.0342) .
\end{gathered}
$$

Main facade windows

First floor

Lighting aperture width $=1.75 / 2.850=0.614$.

Lighting aperture height

\section{Second floor}

Lighting aperture width $=1.75 / 4.5=0.614$.

Lighting aperture height
Third floor

$\frac{\text { Lighting aperture width }}{\text { Lighting aperture height }}=1.75 / 1.75=1$.

A dimension analysis of the polytechnic institute building reveals an adherence to the golden section principle in the designs of the architects of the past.

The spacing of the facade columns and the measurements of the stylobates, entablatures, and pediments, which we analyzed in relation to the Parthenon proportions, once again highlight how the architects of the past perceived and mentally processed the harmony of the world, how they managed to create a flawless architectural form, and why and how the fruits of human labor are connected with the fundamental laws of the universe.

The golden section principles also (indirectly) apply to our color perception of the play of volume and light within the architectural environment around us (Safiulina and Shmurnov, 2014; Radzyukevich and Marchenko, 2015). It is common knowledge that the human brain automatically absorbs up to $90 \%$ of visual cues as part of visual perception. Therefore, the perfectly measured form that follows the golden section principle subconsciously encourages our mind to process the features of the architectural landmark, its color scheme, dimensional composition, or the surrounding landscaped parks (Gorneva et al. 2013; Prokofieva, 2015). The analysis of the color substance that contributes to the generalized perception of architectural solutions, with respect to their dimensions and color (spectral) composition, applies the essential principles of the golden section not only to the proportions and division of the lines, segments, details but also to the balance and harmony that should be maintained when selecting cold and warm colors and their respective wavelengths. When making a fraction of their proportions, we arrive at the same number, 1.6 (with a slight approximation).

The magic of the number 1.6 and its profound impact of creating a perfect harmony of forms and colors gives human beings an instinctive drive towards creative pursuits.

\section{Conclusion}

In the light of modern urban planning policy, it is highly relevant to radically increase urban comfort and reduce the number of cities with an unfavorable environment, in addition to designing a procedure that will allow the new generation of architects to become directly involved in ensuring a comfortable quality of life in cities. One of today's main goals is the creation of an environment that favors sustainable development, as dictated by the concept for the development of historical settlements, the support and promotion of cultural and tourism opportunities, and the development of a cultural heritage economy up to 2030, approved by the Ministry of Culture of the Russian Federation. The program of 
transforming the architectural environment is aimed at integrating the modern additions organically into the urban planning structure while retaining the original development and informed by studying the architectural environment and the objects that shape it. Since the integrity of the architectural environment is primarily ensured by the complementary scale and proportionate dimensions and elements of different buildings, one of the fundamental factors of the transformation described above is the use of modern design techniques that are based on a comparative analysis of classical design methods with historical roots, in addition to the main systems of architectural modules and proportions.

The architectural environment of a historical settlement continues to form throughout the entire period of the settlement's existence; history shows that architects from different historical periods keep returning to the classical systems of measuring proportions, which they interpret in the context of their time's socio-economic conditions and construction technology progress. In this regard, even as our rapidly changing reality abounds with technocratic innovations, we must not forget the classical canons of the architect's profession. The theory of the golden section reflects the unbreakable bonds of historical continuity that exist between the discovery of the geometric laws of the universe and the creation of today's man-made architectural landmarks. 


\section{References}

Bondarenko, I. A. (2019). Composition of the Parthenon in relation to the Temple of Zeus in Olympia: proportional observations. Questions of the History of World Architecture, 1, pp. 43-60. DOI: 10.25995/NIITIAG.2019.12.1.002

Gamm, M. V. and Gorovenko, L. A. (2016). Calculating the adjustments for perspective control when designing buildings and structures. In: Collected Works of the Winners of the $22^{\text {nd }}$ Student Conference at the Armavir Institute of Mechanics and Technology, pp. 70-73.

Gorneva, O. S., Orzhekhovskaya, R. Ya. and Titov, S. S. (2013). Information signal analysis of proportion systems in architecture and fine art. Architecton. Proceedings of Higher Education, 4, pp. 93-99. [online] Available at: http://archvuz.ru/2013_4/11/ [Date accessed 13.08.2020].

Gorovenko, A. D. and Gorovenko, L. A. (2017). Organic architecture and its potential uses in urban development. In: Development of the Nature Conservation System and Urban Ecology. Proceedings of the Regional Scientific and Practical Online Youth Conference, pp. 237-242.

Grinchenko, S. N. and Shchapova, Yu. L. (2018). Archaeolith: archaeological sub-epoch, Homo habilis archaeolithicus, information technologies, space, time, material «production». e-Almanac Space and Time, 16 (3-4). DOI: $10.24411 / 2227-9490-2018-12021$.

Guseva, S. A. and Pravdolyubova, S. S. (2017a). Golden section in the architectural landmarks of the Ryazan Region. In: Issues of Efficiently Using Society's Research Potential: Proceedings of the International Scientific and Practical Conference. In 2 parts. Part 2, pp. 264-267.

Guseva, S. A. and Pravdolyubova, S. S. (2017b). Golden section in the architectural landmarks of the Ryazan Region. In: New Technology in Teaching and Production: Proceedings of the $15^{\text {th }}$ Inter-University Scientific and Technical Conference, April 26-27, 2017, Ryazan, Russia, pp. 23-24.

Kalashnikova, O. B. and Gorovenko, L. A. (2016). The use of optical illusions in architecture and construction. International Student Scientific Bulletin, 5, pp. 355-358.

Kvashina, A. M. and Gorovenko, L. A. (2017). Using the proportions of the «golden section» in classical and modern architecture. In: Applied Issues of Exact Sciences: I International Scientific Practical Conference of Graduate and Postgraduate Students, Lecturers, pp. 37-43.

Litvinenko, N. S. and Luchkova, V. I. (2015). Integrating the principles of module systems and proportions with information-spatial optimization objects of architecture. New Ideas of New Century, 1. [online] Available at: http://pnu.edu.ru/ nionc/pub/articles/513/ [Date accessed 25.09.2020].

Pankratova, A. A. (2018). Historic stone buildings of Ryazan: Compositional features of facades. VESTNIK MGSU (Monthly Journal on Construction and Architecture), 13 (4), pp. 435-445. DOI: 10.22227/1997-0935.2018.4.435-445.

Piljasov, J. I. (2012). Anthropometry of «golden section» proportions. Izvestia of Samara Scientific Center of the Russian Academy of Sciences, 14 (2), pp. 532-536.

Prokofieva, I. A. (2015). Geometric expression of «alive square» physical rules in architecture. Zhilishchnoe Stroitel'stvo (Housing Construction), 1, pp. 33-35.

Radzyukevich, A. V. (2014). On the scientific approach to studying proportions in architecture and art. Polzunovsky Vestnik, 1, pp. 159-164.

Radzyukevich, A. V. and Marchenko, Yu. G. (2015). Pyramid of Cheops: sizes and proportions. Vestnik of Tomsk State University of Architecture and Building, 1, pp. 9-22.

Safiulina, Yu. G. and Shmurnov, V. K. (2014). Golden section's numerical approximations in terms of graphics and application. Geometry and Graphics, 2 (2), pp. 15-20. DOI: 10.12737/5585.

Shevelyov, I. Sh. (1995). Form-making. Number. Form. Art. Life. Kostroma: DiAr Publishing House, 166 p.

Shevelyov, I. Sh., Marutayev, M. A. and Shmelyov, I. P. (1990). Golden section: three outlooks on the nature of harmony. Moscow: Stroyizdat, $343 \mathrm{p}$.

Stakhov, A. P. (1984). Codes of the golden proportion. Moscow: Radio i Svyaz, 152 p.

Stakhov, A. P. (2004). Generalized golden sections and a new approach to the geometric definition of a number. Ukrains'kyi Matematychnyi Zhurnal, 56 (8), pp. 1143-1150.

Stakhov, A. P. (2012). Mathematics of harmony. From Euclid to contemporary mathematics and computer science. Naukovedenie, 4. [online] Available at: https://naukovedenie.ru/PDF/33tvn412.pdf [Date accessed 15.08.2020].

Suprun, L. I., Suprun, E. G. and Igosheva, E. D. (2019). Geometry and architecture. The Eurasian Scientific Journal, 11 (1). [online] Available at: https://esj.today/PDF/18SAVN119.pdf [Date accessed 27.10.2020]. 


\title{
ПРАКТИКА ПРИМЕНЕНИЯ ЗОЛОТОГО СЕЧЕНИЯ В АРХИТЕКТУРЕ РЯЗАНИ
}

\author{
Светлана Станиславовна Правдолюбова ${ }^{*}$, Михаил Оганесович Векилян ${ }^{1}$, Геннадий Савельевич \\ Нечипорук ${ }^{1}$, Анна Алексеевна Кожнова ${ }^{1}$, Светлана Александровна Гусева ${ }^{2}$ \\ 1 Рязанский институт (филиал) Московского политехнического университета \\ ул. Право-Лыбедская, 26/53, Рязань, Россия \\ ${ }^{2} \mathrm{OOO}$ «Маранда» \\ ул. Полетаева, 24, Рязань, Россия \\ *E-mail: pravda_63@mail.ru
}

\begin{abstract}
Аннотация
В настоящее время одной из актуальных проблем устойчивого развития исторических поселений является сохранение своеобразия архитектурного облика. В контексте преобразований среды поселений с минимизацией диссонирующего воздействия нового строительства важны исследования объектов застройки, которые составят основы современных методик проектирования. Методы: В статье используется метод геометрического анализа исторических зданий города Рязань, имеющих признаки классической архитектуры и запроектированных архитекторами XIX - XX веков, на соответствие правилам классической композиции, в частности - на применение пропорций по принципу золотого сечения. Результаты: В статье изучается золотое сечение в целом, его история, рассматривается применение правила золотого сечения в архитектуре, показана неразрывная связь архитектуры с геометрией. В ходе работы доказано, что принципы золотой пропорции использовались архитекторами разных эпох. В условиях неизменно высокого интереса к творческому наследию архитекторов XIX - XX веков и необходимости использования их исторического опыта, существует актуальность подхода к современной архитектурной практике с точки зрения использования канонических постулатов классической архитектуры.
\end{abstract}

\section{Ключевые слова}

Золотое сечение, золотая пропорция, объекты культурного наследия, архитектура, геометрический анализ, здания, сооружения, эпоха классицизма, соразмерность, методика в проектировании, геометрическая прогрессия, фасад, колонна, стилобат, антаблемент, капитель, формообразование. 